\title{
Antibiotic Resistance Pattern and Plasmid Profile of Bacteria Isolates from Household Water Distribution Tanks in Ado-Ekiti
}

\author{
T.F. Babalola ${ }^{1}\left(\mathbb{D}\right.$, T.O. Olowomofe ${ }^{2 *}\left(\mathbb{D}\right.$, T.R. Omodara ${ }^{2}$ and T.Y. Ogunyemi ${ }^{3}$ \\ ${ }^{1}$ Department of Environmental Health Sciences, College of Health Science and Technology, ljero-Ekiti, Nigeria. \\ ${ }^{2}$ Department of Microbiology, Faculty of Science, Ekiti State University, Ado-Ekiti, Nigeria. \\ ${ }^{3}$ Health Information Management, Optum 360, United Health group, Minnesota, United States.
}

\begin{abstract}
Water is essential to life. The existence of all forms of life is dependent on an adequate water supply. The exigent need for water supply in homes prompted the construction of water sources and water storage devices in the homes. This however does not guarantee that the water is safe to drink. If the water is safe at the source, it may be contaminated during transportation storage and drawing at home. This study was carried out to determine the microbial counts, antibiotics susceptibility and plasmid profile of bacteria isolates from household water distribution tanks in the Ado-Ekiti metropolis. The total bacteria and coliform counts were determined using the pour plating technique. The antibiotic susceptibility pattern of the isolates was determined using the disc diffusion technique while the plasmid profile of the isolates was determined using the alkaline lysis method and agar gel electrophoresis. The mean total bacteria count of the water sample was $6.96 \log 10 \mathrm{CFU} / \mathrm{ml}$, while the mean total of coliform count is $5.50 \log 10 \mathrm{CFU} / \mathrm{ml}$. The isolates with multiple antibiotics resistance belonged to five bacteria genera namely: Escherichia, Pseudomonas, Klebsiella, Enterobacter and Proteus. The plasmid analysis showed that four of the resistant strains had multiple plasmids, Enterobacter aerogens had 3 plasmids (1kb, 1.5kb and 2kb), Pseudomonas aeruginosa and Klebsiella aerogens had two plasmids (1kb, 1.5kb) respectively while Proteus vulgaris and Escherichia coli had no plasmid.
\end{abstract}

Keywords: Water sanitation, coliforms, plasmids, Antibiotic susceptibility, water storage tanks

\begin{abstract}
*Correspondence: motunde21@yahoo.com
(Received: April 15, 2021; accepted: August 03, 2021)

Citation: Babalola TF, Olowomofe TO, Omodara TR, Ogunyemi TY. Antibiotic Resistance Pattern and Plasmid Profile of Bacteria Isolates from Household Water Distribution Tanks in Ado-Ekiti. J Pure Appl Microbiol. 2021;15(3):1697-1704. doi: 10.22207/ JPAM.15.3.66

(C) The Author(s) 2021. Open Access. This article is distributed under the terms of the Creative Commons Attribution 4.0 International License which permits unrestricted use, sharing, distribution, and reproduction in any medium, provided you give appropriate credit to the original author(s) and the source, provide a link to the Creative Commons license, and indicate if changes were made.
\end{abstract}




\section{INTRODUCTION}

Water is the most essential commodity for human consumption. Adequate supply of potable water is essential for the well-being of all people around the world $^{1,2}$. Human activities such as agriculture, trading, industries cannot function properly without adequate water supply.

The two most common sources of drinking water are surface water and ground water ${ }^{3,4}$. Rural communities in Nigeria usually source their water for drinking and domestic purposes from streams and well while those in urban areas source water from well, boreholes and water distribution centers. Due to the inevitable importance of water and scarcity especially during dry season, they store water in buckets, drums, basins and tanks for easy accessibility. Meanwhile, water from these sources have been reported to contain certain pathogens and other contaminants which compromise the aesthetic and microbial quality of the water ${ }^{5,6,7}$.

Most homes of middle income earners in Ado-Ekiti pump their water from the source (well, borehole) and store in storage tanks. The tank is piped to all sections of the house for convenience and easy accessibility to water when needed. It is assumed that over time, organic particulates and microorganisms in the water will settle via sedimentation. The pipes also can be coated with organic matter which may serve as nutrient for the growth of microorganisms.

Regular washing and disinfection of tanks, inspection of pipes for leakages, semi-annual testing of water for total coliforms and faecal coliforms which are means of accessing the quality of water are not practiced in the homes. Most of them are usually carried away by the comfort of easy and regular accessibility to water and forget to wash the tanks and take other precaution measures.

Inadequate storage conditions and vulnerable water storage containers have been documented as factors contributing to increased microbial contamination of household water ${ }^{8,9}$. Increased risks of waterborne diseases from inadequately stored water compared to water stored in an improved vessel have also been reported ${ }^{10}$. Loss of disinfectant residual, bacteria re-growth, poor turn over and excessive detention time are the common problems in storage tanks and reservoirs ${ }^{11}$.

The deterioration of water quality as a result of anthropogenic activities, indiscriminate discharge of wastes has been reported ${ }^{12,13,14}$. Polluted water has been identified as the major cause of water borne disease and epidemics looming the developed and developing countries ${ }^{15}$. Waterborne diseases represent major health problem in many parts of the world and reported to cause about 842,000 diarrhoea deaths per year 16 . Many diseases such as Cholera, typhoid fever, bacillary dysentery, and others can be transmitted through this route ${ }^{10}$. Bacteria genera commonly isolated from water includes; Enterobacter, coliforms and Escherichia coli ${ }^{17}$. Their ability to resist the inhibitory effect of antibiotics is of great public health concern.

Microbial contamination of drinking water remains a significant threat to living organisms and therefore constant vigilance is essential because many pathogens can be transmitted through the supply of water ${ }^{18}$. Hence, this study aimed at determining the microbial quality of water from household water distribution tanks in Ado-Ekiti metropolis. This will provide baseline information on the quality of the water and create awareness for prevention of waterborne diseases.

\section{MATERIAL AND METHODS Collection of Samples}

Water samples were collected in sterile sample bottles from household distribution tanks from ten different locations in Ado-Ekiti metropolis ( $7^{\circ} 37^{\prime} 16^{\prime \prime}$ $\left.N 5^{\circ} 12^{\prime} 17^{\prime \prime} \mathrm{E}\right)$. The samples were transported in ice packs to the laboratory for immediate microbiological analyses.

\section{Isolation and Identification of Isolates}

Total heterotrophic bacteria and coliforms were isolated from the samples using ten-fold serial dilution and pour plate method as described by Oluyege ${ }^{6}$. Pure culture was stored on nutrient agar slants and stored at $4^{\circ} \mathrm{C}$. The isolates were subjected to morphological and biochemical tests such as Gram staining, motility test, catalase test, coagulase test, oxidase test, indole test, citrate test, urease test, methyl red test and their identities were determined according to Bergey's Manual of Determinative Bacteriology ${ }^{19}$.

\section{Antibiotic Susceptibility test of the Isolates}

The antibiotics susceptibility of the isolates was determined by the disk diffusion method on Mueller-Hilton agar according to Cheesbrough ${ }^{20}$. The isolates were tested against ten ABTEK antibiotic discs which comprised of ceftazidine (CAZ) $30 \mu \mathrm{g}$, tarivid $(10 \mu \mathrm{g})$, gentamycin (GEN) $10 \mu \mathrm{g}$, Septrim $(30 \mu \mathrm{g})$, ofloxacin (OFL) $5 \mu \mathrm{g}$, augmentin (AUG) $30 \mu \mathrm{g}$, ofloxacin (OFL) $5 \mu \mathrm{g}$, ciprofloxacin (CPR) $5 \mu \mathrm{g}$, Perfloxacin ( $5 \mu \mathrm{g}$ ) and Sparfloxacin $(10 \mu \mathrm{g})$. The inoculums were standardized by adjusting their densities to the turbidity of a Barium sulphate $\left(\mathrm{BaSO}_{4}\right)$ ( $0.5 \mathrm{McF}$ arland turbidity standard). One milliliter of each of the standardized broth cultures of the test isolates were swab on the Mueller Hinton agar plates, the antibiotic discs were placed firmly on solidified plates and incubated for 24 hours at $37^{\circ} \mathrm{C}$. Un-inoculated agar plates with antibiotics served as the 
Table 1. Survey of water sources and sanitary practices in households in Ado-Ekiti

\begin{tabular}{lcccc}
\hline Households & $\begin{array}{c}\text { Water } \\
\text { source }\end{array}$ & $\begin{array}{c}\text { Frequency of cleaning } \\
\text { water tanks }\end{array}$ & $\begin{array}{c}\text { Mode of } \\
\text { disinfection }\end{array}$ & $\begin{array}{c}\text { Proximity of water source } \\
\text { to septic tank }\end{array}$ \\
\hline $\mathrm{N}=15$ & $\begin{array}{c}\text { Well (60\%) } \\
\text { Borehole (40\%) }\end{array}$ & $\begin{array}{c}\text { Never (47\%) } \\
\text { Yearly (53\%) }\end{array}$ & $\begin{array}{c}\text { None (47\%) } \\
\text { Water guard (33\%) } \\
\text { Chlorination (20\%) }\end{array}$ & $\begin{array}{c}<50 \mathrm{ft} \mathrm{(60 \% )} \\
\end{array}$ \\
\end{tabular}

Table 2. Total Bacteria Count and Coliform Count of Isolated Bacteria from Household Water Distribution Tanks in Ado-Ekiti

\begin{tabular}{lcc}
\hline Households & $\begin{array}{c}\text { Total Bacteria } \\
\text { Count } \\
\left(\log _{10} \text { CFU/ml) }\right.\end{array}$ & $\begin{array}{c}\text { Total Coliform } \\
\text { Count } \\
\left(\log _{10} \text { CFU/ml) }\right.\end{array}$ \\
\hline A & $8.17 \pm 0.05$ & $6.35 \pm 0.07$ \\
B & $7.41 \pm 1.25$ & $5.52 \pm 0.02$ \\
C & $7.31 \pm 0.08$ & $7.60 \pm 1.21$ \\
D & $5.10 \pm 0.05$ & $4.73 \pm 0.08$ \\
E & $6.71 \pm 0.06$ & $4.84 \pm 0.02$ \\
F & $7.35 \pm 1.05$ & $5.18 \pm 1.12$ \\
G & $6.84 \pm 0.02$ & $4.02 \pm 1.05$ \\
I & $8.25 \pm 0.05$ & $5.45 \pm 0.07$ \\
J & $6.16 \pm 1.08$ & $4.23 \pm 0.04$ \\
K & $7.08 \pm 0.08$ & $6.22 \pm 0.07$ \\
L & $5.32 \pm 0.03$ & $4.14 \pm 1.21$ \\
M & $8.01 \pm 1.23$ & $6.68 \pm 1.05$ \\
N & $7.79 \pm 1.06$ & $7.23 \pm 1.11$ \\
O & $7.15 \pm 1.03$ & $6.30 \pm 1.31$ \\
P & $5.89 \pm 0.04$ & $4.10 \pm 0.04$ \\
Mean & 6.96 & 5.50 \\
\hline
\end{tabular}

Values are the mean and standard deviation of three replicates control. The diameter of the zone of growth inhibition was measured to the nearest whole millimeter and interpreted on the basis of CLSI guideline ${ }^{21}$.

\section{Plasmid Profiling of Antibiotic-resistant Isolates}

Plasmid analysis was performed on representative isolates selected on the basis of their antibiotic resistance phenotypes.

\section{Extraction of Plasmid}

Plasmid extraction was carried out using Fast and Easy Plasmid Mini-prep Kit as described by Olowomofe ${ }^{22,23}$. The extracted plasmid DNA was separated using agarose gel electrophoresis. The plasmid DNA was loaded into pre-cast wells in the gel and electric current (100V) was applied for 1 hour. The agarose gel was stained with $0.5 \mathrm{ug} / \mathrm{ml}$ ethidium bromide for 20 minutes and visualized by UV-trans illumination according to Robins-Browne ${ }^{24}$.

Statistical analysis

Standard deviation of the mean of data obtained from this study were determined using 2010 Microsoft Excel.

\section{RESULTS}

\section{Water storage and sanitation practices}

A total of fifteen households were examined in the study. Sixty percent sourced their water from well while remaining forty percent sourced water from borehole. Forty-seven percent of the households do not engage in regular cleaning of their water tanks while fifty-three percent clean their tanks once in a year. Water guard and chlorination were the methods of disinfection used in these households. Sixty percent of the households had their septic tanks in less than 50 feets to their water source while the septic tanks and water source of the remaining forty percent were 50 to 100ft apart (Table 1).

Mean total bacteria and total coliforms counts

The enumeration of heterotrophic and coliforms in water samples from household water distribution tank in Ado-Ekiti is shown in Table 2. Substantial count of bacteria was recovered from water samples from all the household examined. The mean total bacteria count and total coliforms were $6.96 \mathrm{CFU} /$ $\mathrm{ml}$ and $5.50 \mathrm{CFU} / \mathrm{ml}$ respectively.

Based on the cultural and biochemical characteristics, the most frequent bacteria isolated from household water distribution tanks were Escherichia coli (20\%), Pseudomonas aeruginosa (14\%), Proteus vulgaris (16\%), Klebsiella aerogenes (19\%), Enterobacter aerogenes (9\%), Serratia marcescens (8\%), Bacillus sp. (8\%) and Enterococcus sp. (6\%) as indicated in Table 3. Antibiotics susceptibility pattern of the isolates

The antibiotics susceptibility test of the bacteria isolates reflects variation in their response to the different antibiotics examined as shown in Table 4. Their average percentage resistances to antibiotics are as follows: Amoxyllin (92\%), Gentamycin (81\%), Augmentin (80\%), Sparfloxacin (78\%), Chloraphenicol (75\%), Perfloxacin (29\%), Ofloxacin (24\%), Streptomycin (53\%), Cotrimoxazole (42\%), and Ciprofloxacin (46\%).

The multiple antibiotics resistant pattern of the bacteria isolates is shown in Table 5 . The isolates displayed different resistance pattern to the antibiotics, 
Table 3. Percentage Occurrence of Bacteria isolated from Household Water Distribution Tanks in Ado-Ekiti

\begin{tabular}{lc}
\hline Isolates & $\begin{array}{c}\text { Percentage of } \\
\text { occurrence (\%) }\end{array}$ \\
\hline Escherichia coli & 20 \\
Pseudomonas aeruginosa & 14 \\
Proteus vulgaris & 16 \\
Klebsiella aerogenes & 19 \\
Enterobacter aerogenes & 9 \\
Serratia marcescens & 8 \\
Bacillus sp & 8 \\
Enterococcus sp & 6 \\
Total & 100 \\
\hline
\end{tabular}

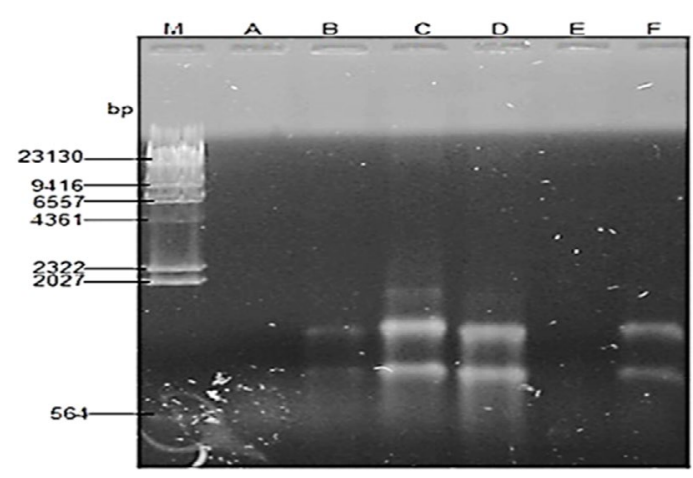

Key: A: Proteus vulgaris, B: Pseudomonas aeruginosa, C: Escherichia coli, D: Enterobacter aerogenes, E: Serratia marcescens, F: Klebsiella aerogenes, bp - represents molecular sizes

Fig. 1. Plasmid Profile of Antibiotics resistant Bacteria isolated from household water distribution tanks in Ado-Ekiti
Pseudomonas aeruginosa, Escherichia coli and Klebsiella aerogenes were resistant to $70 \%$ of the antibiotics examined, while Enterobacter aerogenes, Serratia marcescens and Proteus vulgaris showed resistance to $60 \%$ of the antibiotics and Bacillus sp. was resistant to $40 \%$.

\section{Plasmid profiling of the isolates}

The plasmid profile of the isolates with multiple antibiotic resistance is shown in Figure 1. The result showed that four out of the resistant strains harbored multiple plasmids, Escherichia coli had three plasmids ( $1 \mathrm{~kb}, 1.5 \mathrm{~kb}$ and $2 \mathrm{~kb})$, Pseudomonas aeruginosa, Klebsiella aerogenes and Enterobacter aerogenes had two plasmids with $1 \mathrm{~kb}, 1.5 \mathrm{~kb}$ each while Proteus vulgaris and Serratia marcescens had no plasmid.

\section{DISCUSSION}

The numerous reports about the occurrence of pathogenic microorganisms in drinking water, their ability to resist antibiotics and associated diseases prompted this study, to access the microbial quality of water in storage tanks which serve as drinking and other domestic purpose for majority of homes in Ado-Ekiti.

Total bacteria and total coliform count of all the water samples analyzed in this study revealed high microbial contamination of the water (Table 2). The limit of $<500 \mathrm{CFU} / \mathrm{ml}$ of heterotrophic bacteria and zero coliform or E. coli per $100 \mathrm{ml}$ of water as stipulated by WHO, USEPA, ISI 25,18 was exceeded in all the samples. Non-conformity of these water samples to the WHO standard decreased the water quality and renders them unfit for human consumption ${ }^{26}$. Previous researches on microbial assessment of drinking water sources have also reported high heterotrophic bacteria and coliform counts in different water sources and many

Table 4. Antibiotics Resistance Pattern of Bacteria isolated from Household Water Distribution Tanks in Ado-Ekiti

\begin{tabular}{|c|c|c|c|c|c|c|c|c|c|c|c|}
\hline \multirow[t]{2}{*}{ No. } & \multirow[t]{2}{*}{ Isolates } & \multicolumn{10}{|c|}{ Antibiotic resistance patterns of the bacterial isolates (\%) } \\
\hline & & AM & $\mathrm{AU}$ & $\mathrm{CN}$ & PEF & OFX & $S$ & COT & $\mathrm{CHL}$ & SP & $\mathrm{CPX}$ \\
\hline 1. & Pseudomonas aeuriginosa $(n=12)$ & 100 & 100 & 92 & 28 & 32 & 98 & 20 & 100 & 100 & 78 \\
\hline 2. & Proteus vulgaris $(n=10)$ & 100 & 100 & 75 & 20 & 18 & 50 & 35 & 30 & 98 & 50 \\
\hline 3. & Escherichia coli $(n=15)$ & 100 & 92 & 80 & 25 & 30 & 70 & 45 & 50 & 100 & 45 \\
\hline 4. & Klebsiella aerogenes $(\mathrm{n}=10)$ & 98 & 72 & 98 & 38 & 28 & 65 & 58 & 100 & 100 & 35 \\
\hline 5. & Enterobacter aerogenes $(n=10)$ & 92 & 62 & 75 & 35 & 22 & 45 & 50 & 98 & 50 & 30 \\
\hline 6. & Serratia marcescens $(n=8)$ & 90 & 75 & 80 & 23 & 15 & 35 & 50 & 58 & 65 & 35 \\
\hline 7. & Bacillus sp $(\mathrm{n}=5)$ & 75 & 68 & 72 & 30 & 25 & 28 & 45 & 100 & 65 & 50 \\
\hline \multirow[t]{2}{*}{8.} & Enterococcus sp $(\mathrm{n}=7)$ & 80 & 70 & 75 & 35 & 25 & 30 & 32 & 62 & 45 & 45 \\
\hline & Average resistance & 92 & 80 & 81 & 29 & 24 & 53 & 42 & 75 & 78 & 46 \\
\hline
\end{tabular}

KEY: AMX - Amoxycilin, CPX-Ciprofloxacin, , OFL-Ofloxacin, CHL- Chloraphenicol, SP- Sparfloxacin, PEF- Perfloxacin, COTCotrimoxazole, S- Streptomycin, CN- Gentamycin, AU- Augmentin. 
Table 5. Multiple antibiotic resistance patterns of bacteria isolates from Household Water Distribution Tanks in Ado-Ekiti

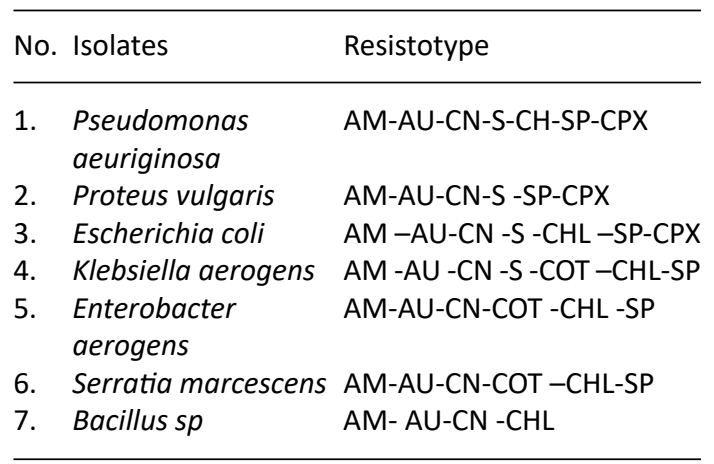

KEY: AMX-Amoxyllin, CPX-CiprofloXacin, , OFL-Ofloxacin,CHLChloraphenicol, SP- Sparfloxacin, PEF- Perfloxacin, COTCotrimoxazole, S- Streptomycin, CN- Gentamycin, AUAugmentin.

of these water sources exceeded the permissible limits for quality water ${ }^{27,28,6}$. Eight bacteria genera recovered from the water samples: Escherichia coli, Pseudomonas aeruginosa, Proteus vulgaris, Klebsiella aerogenes, Enterobacter aerogenes, Serratia marcescens, Bacillus sp. and Enterococcus sp. have been isolated from different water sources ${ }^{29}$. The presence of Escherichia coli in the water is an indication that the household water has been faecally polluted. It also correlates with past studies which reported Escherichia coli as an organism that is commonly encountered in different water sources such as rivers, streams, rain water, well water, underground water and even pipe borne water ${ }^{30}$. Sixty percent of the households examined in this study sourced their water from well while the remaining $40 \%$ source their water from borehole (Table 1). Prevalence of bacteria from these genera have been reported in underground water ${ }^{31}$. High frequency of Pseudomonas species in household water also corroborates the report of Kawther and Suaad $^{32}$. Factors such as, their raw water source, treatment process employed and hygienic practices observed could influence microbial contaminations of household water ${ }^{33}$. The possibility of cross contamination of sewage and water in these household cannot be ruled out because larger percentage $(60 \%)$ of them had their wells in close proximity ( $<50 \mathrm{ft}$ ) to the septic tank (Table 1). Movement of water underground can lead to the sewer contaminating the water. Hence, the source of these bacteria is therefore linked to the water source rather than the storage tank.

Fifty-three percent of the households claimed they treated their water yearly with water guard or chlorination while others did not treat theirs. However, the effect of the treatment of the water by some of
Table 6. Plasmid profiling of the multiple resistant Bacteria isolated from Household water Distribution Tanks in Ado-Ekiti

\begin{tabular}{lcc}
\hline Isolates & $\begin{array}{c}\text { Number of } \\
\text { Plasmid }\end{array}$ & $\begin{array}{c}\text { Molecular } \\
\text { Weight }\end{array}$ \\
\hline $\begin{array}{l}\text { Proteus vulgaris } \\
\text { Pseudomonas }\end{array}$ & Nil & Nil \\
$\begin{array}{l}\text { aeruginosa } \\
\text { Escherichia coli }\end{array}$ & 2 & $1 \mathrm{~kb}, 1.5 \mathrm{~kb}$ \\
$\begin{array}{l}\text { Enterobacter aerogens } \\
\text { Serratia marcescens }\end{array}$ & 2 & $1 \mathrm{~kb}, 1.5 \mathrm{~kb}, 2 \mathrm{~kb}$ \\
Klebsiella aerogens & $\mathrm{Nil}$ & $1 \mathrm{~kb}, 1.5 \mathrm{~kb}$, \\
\hline
\end{tabular}

these households was not reflected as they also had high bacteria counts as the untreated water. This could be due to the loss of residual concentration of disinfectant used. Also, accumulation of organic matter in the tanks and pipes over time could enhance the growth of these bacteria since the households do not practice regular washing and disinfection of the water and the tanks which could have removed these contaminants. Once the water in the tank is exhausted, they immediately pump another water and overtime, the tank become heavily contaminated with organic and microbial contaminants.

The presence of these microbes in the water can present serious wellbeing dangers to consumers in general especially the immunocompromised individuals when the water is distributed.

Water borne diseases are usually combated with antibiotics. Due to their potency, they have gained global recognition as agents for treating infections. However, some bacteria have developed mechanisms of resisting the inhibitory effect of this group of antimicrobial agents. Some bacteria build living wall in response to exposure to antibiotics creating a physical barrier that shield them from and contribute further to the growing problems of drug resistant infection $^{34}$. Bacteria isolated in this study exhibited similar characteristics of resisting multiple antibiotics examined. Previous studies accounted for the prevalence of antibiotic-resistant bacteria in surface and ground waters $^{35,36}$.

High resistance was exhibited by the bacteria to Amoxyllin (92\%), Gentamycin (81\%), Augmentin (80\%), Sparfloxacin (78\%), and Chloraphenicol (75\%). These antibiotics are the commonly prescribed drugs for people diagnosed with water related or other infections. Resistance of these bacteria to the antibiotics calls for public health concern. Mulamattathil ${ }^{37}$ likewise revealed that all bacteria from surface and drinking water in Mafikeng, South Africa analyzed were resistant to Erythromycin, Trimethoprim, and Amoxicillin. The 
isolates also displayed resistance to multiple antibiotics (4 to 7). Bacteria from these genera have been reported to possess multidrug resistance ${ }^{38,39}$.

Six (6) multi-drug resistant bacteria isolated from household water samples were analyzed for plasmid out of which 4 harbored more than one plasmid. This conforms with the findings of Atuanya ${ }^{40}$ who isolated 45 antibiotics resistant bacteria from water samples and detected 31 plasmids in 14 of 45 antibiotics resistant strains with 10 carrying multiple plasmids. All the four (4) isolates containing the plasmids were resistant to Amoxyllin. The result of this study was in accordance with Ash $^{41}$ who studied antibiotics resistance of gram negative bacteria from ground water in the United States and showed that their resistance to Augmentin, Amoxyllin and Erythromycin were plasmid mediated. The plasmids isolated were between the ranges of $1 \mathrm{~kb}-2 \mathrm{~kb}$ which was similar to the observation of Smith ${ }^{42}$.

Plasmids are double stranded extrachromosomal genetic elements which reproduce autonomously. They have been recognized in numerous microbes however, they are some of the time found in eukaryotic cells ${ }^{43}$. It is notable that plasmids are quite possibly one of the most important facilitating agents in the fast spreading of antibiotics resistance among bacteria ${ }^{44}$. The microbial resistance genes frequently carried on plasmids have the ability to replicate and possibly the potential for self-transmission.

The incidence of plasmids among bacteria with multiple resistance to antibiotics in this study is alarming because plasmids have been identified as one of such movable elements through which resistance and foreign genes are being transmitted in niches ${ }^{45,46}$. Genes that influence bacterial virulence are also frequently found on plasmids. Consequently, non-pathogenic and antibiotic susceptible bacteria can become pathogenic and resistant to antibiotics over time as a result of transmission of plasmids. This pose a health threat to the consumers because pathogenic bacteria from water sources have been identified as etiological agents of water borne diseases.

\section{CONCLUSION}

This study revealed water from household distribution tanks analyzed exceeded the permissible limits for coliforms and heterotrophic bacteria counts. Bacteria from the water samples were resistant to multiple antibiotics and the resistant strains had plasmids which could spread the resistance ability to non-resistant strains. The findings showed the water were contaminated and unfit for consumption. There is therefore need for regular washing of water storage tanks and routine disinfection of stored water to avert outbreak of waterborne diseases.

\section{ACKNOWLEDGEMENT}

None.

\section{CONFLICT OF INTEREST}

of interest.

The authors declare that there is no conflict

\section{AUTHOR'S CONTRIBUTION}

All authors listed have made substantial, direct and intellectual contributions to the work and approved it for publication.

\section{FUNDING}

None.

\section{DATA AVAILABILITY}

All datasets generated or analyzed during this study are included in the manuscript.

\section{ETHNIC STATEMENT}

Not applicable.

\section{REFERENCES}

1 Pund DA, Aanorkar RP. Study of some physicochemical parameters of drinking water sources in Tem bhurkheda and Jarud Region Dist. Amravati, MS, India. Int. Res. J. Environment Sci. 2013; 2(10):93-95.

2. Alhassan H, Kwakwa PA. When water is scarce: the perception of water quality and effects on the vulnerable. Journal of Water, Sanitation and Hygiene for Development, 2014; 4: 43-50. doi: 10.2166/ washdev.2013.140

3. Getso BU, Mustapha A, Abubakar MM, Tijjani A. Assessment of Borehole Water Quality for Domestic Use in Three Selected Wards in Wudil Local Government Area, Kano State. Journal of Environmental Science Studies, 2018;1(1):1-5. doi: 10.20849/jess.v1i1.394

4. The World Water, International World Water Day, United Nations Conference on Environment and Development (UNCED). Washington DC, USA: Island Press. 2009.

5. Benjamin L, Atwill ER, Jay-Russell M, et al. Occurrence of generic Escherichia coli, E. coli 0157 and Salmonella spp. in water and sediment from leafy green produce farms and streams on the Central California coast. International Journal of Food Microbiology, 2013 ;165.1: 65-76. doi: 10.1016/j.ijfoodmicro.2013.04.003

6. Oluyege JO, Dada O, Oluyege AO, Olowomofe TO. Multiple antibiotic resistance index of Escherichia coli isolated from drinking water sources in Ado-Ekiti, Ekiti State. The Experiment, 2014;28(1):1896-1905. doi: 10.3242/expj.v19j3.7689.

7. Onuoha C. Antibiotics Susceptibility Pattern of Escherichia coli Isolated from Well Water in Afikpo, South Eastern Nigeria. AASCIT Journal of Biology, 2015 ;3:38-42.

8. Lehloesa LJ, Muyima NYO. Evaluation of impact of household treatment procedures on the quality of 
groundwater supplies in the rural community of the Victoria District, Eastern Cape. Water SA, 2000 ;26(2):285-290.

9. Akoto $\mathrm{O}$, Adiyiah J. Chemical analysis of drinking water from some communities in the Brong Ahafo region. Int. J. Environmental Science Technology, 2007;4(2): 211-214.

10. Cabral JPS. Water microbiology. Bacterial pathogens and water. International Journal of Environmental and Public Health, 2010;7(10): 3657-3703. doi: 10.3390/ ijerph7103657

11. Duer. The science of mixing and improving water quality in water storage tanks; 2006. http://waterworld.com/ content/ww/en/whitepapers/. Accessed Mar, 2015.

12. Obi CL, Potgieter N, Bessong PO, Matsaung G. Assessment of the microbial quality of river water sources in rural Venda communities in South Africa, Water SA, 2002; 28(3):287-292. doi: 10.4314/wsa. v28i3.4896

13. Sharma A, Dubey N, Sharan B. Characterization of Aeromonads isolated from the river Narmada, India, International Journal of Hygiene and Environmental Health, 2005;208(5): 425-433. doi: 10.1016/j. ijheh.2005.03.007

14. US Environmental Protection Agency (EPA). Quick guide to drinking water sample collection, Region 8 Laboratory 16194 W. 45th Dr. Golden, CO 80403, 2016

15. Onyenekenwa CE. Effects of Water and Sanitation Crisis on Infants and Under-five Children in Africa. Journal of Environmental Science and Technology, 2011;4(2):103111. doi: 10.3923/jest.2011.103.111

16. WHO. Water-related diseases. Environmental Management for Vector Control. World Health Organization 2014, (http://www.euro.who.int/ pubrequest)

17. Calva JJ, Sifuentes-Osornio J, Ceron C. Antimicrobial resistance in faecal flora: Longitudinal communitybased surveillance of children from urban Mexico. Antimicrobial Agents Chemotherapy. 1996 ;40(7): 1699-1702. doi: 10.1128/AAC.40.7.1699

18. World Health Organization. Heterotrophic plate counts and drinking water safety. The significance of HPCs for water quality and human health. 2003; Edited by Bartram J, Cotruvo J, Exner M.

19. Holt GJ, Krieg NR. Sneath PHA, Stanley JT, Williams ST. Bergey's manual of determinative bacteriology. $9^{\text {th }} \mathrm{Ed}$; Baltimore md; Williams and wikins. Pub.co, Maryland, 1994;786.

20. Cheesbrough M. District Laboratory Practice in Tropical Countries (Part ii). Cambridge University Press, 50-150. https://www.medbox.org/preview/5255d6e1-05d441a9-beb2-02b60e695ecc/doc.pdf

21. CLSI. Performance standards for antimicrobial susceptibility testing; fifteenth informational supplement, Clinical and Laboratory Standard Institute Wayne, Pa. M100-S15, 2012;25: 1.

22. Olowomofe TO, Babalola TF, Oluyide OO, Adedayo O. Microbial Assessment of In-door Air and Equipment
Used in Banks within Ekiti State University, Ado-Ekiti, Ekiti State, Nigeria. Annual Research \& Review in Biology, 2019; 33(5):1-13 doi: 10.9734/arrb/2019/ v33i530134

23. Baserisalehi M and Bahador N. A study on relationship of plasmid with Antibiotic Resistance in Thermophilic Campylobacter spp. Isolates from Environmental Samples Biotechnology, 2008;7(4): 813-817. doi: 10.3923/biotech.2008.813.817

24. Robins-Browne RM, Bordun AM, Tauschek M, et al. Escherichia coli and community-acquired gastroenteritis: Melbourne, Australia. Emerg Infect Dis. 2004;10(10):1797-1805. doi: 10.3201/eid1010.031086

25. US Environmental Protection Agency (EPA). "Quality drinking water. 2015. http://www.epa.gov/sites/ default/files/201511/documents/drinking_water_ sample_collection.pdf

26. World Health Organization, 2006. Protecting Groundwater for Health: Managing the Quality of Drinking Water Sources. IWA Publishing, London. https://www.who.int/water_sanitation_health/ publications/PGWsection1.pdf?ua=1

27. Onwa NC, Uzomaka IC, Maduako AL, Elom EE, Ikeanumba MO, Nwode VF. Antibiotic Susceptibility of Bacterial Species Isolated from Underground Waters in Abakaliki Metropolis of Ebonyi State, Nigeria. International Journal of Pharmaceutical Science Invention(IJPSI), 2019; 8(2):55-65.

28. Ekhosuehi A, Akharame MO, Obayuwana P. Bacteriological quality and antibiogram of isolates from potable water sources in Ekosodin community, Benin City, Nigeria. Journal of Applied Science and Environmental Management,2018;22(1) 129-133. doi: 10.4314/jasem.v22i1.24

29. Olorunjuwon B, Adeleke O, Temitope O. Microbial Quality and Antibiotic Susceptibility Profile of Bacterial Isolates from borehole Water Used by Some Schools in ljebu-Ode, Southwestern Nigeria. Scholars Acad. J. Biosci., 2013;1(1):4-13

30. Environment Protection Agency, EPA. US Environment protection agency: Safe drinking water act amendment, 2002. P. EPA $816-F-03-016$.

31. Edema MO, Atayese AO. Pure water syndrome: bacteriological quality of sachet- packed drinking water sold in Nigeria. African Journal of Food, Agriculture, Nutrition and Development.2011;11(1):4595-4609. doi: 10.4314/AJFAND.V1111.65885

32. Kawther FA, Suaad SA. Mineral and microbial contents of bottled water and tap water in Riyadh, Saudi Arabia. Middle-East Journal of Scientific Research. 2007; 2(3): 151-156.

33. Geldreich EE. Microbial quality of water supply in distribution system. Published, 2019 by CRC Press.

34. Matic L, Taddei F, Radman M. Genetics barriers among bacteria. Trends in Microbiology,1996;4(2):69-73. doi: 10.1016/0966-842X(96)81514-9

35. O'Dwyer J, Hynds P, Pot M, Adley C, Ryan MP. 
Evaluation of Levels of antibiotic Resistance in Groundwater Derived $E$. coli Isolates in the Mid-West of Ireland and Elucidation of Potential Predictors of Resistance. Hydrogeol. J. 2017;25:939-951. doi: $10.1007 / \mathrm{s} 10040-017-1546-8$

36. Efuntoye O, Apanpa O. Status of Contamination and Antibiotic Resistance of Bacteria from well water in Ago-Iwoye, Nigeria. J. Appl. Biosci. 2010;35:2244-2250.

37. Mulamattathil GS, Bezuidehout C, Mbewe M, Ateba CN. Isolation of Environmental Bacteria from Surface and Drinking Water in Mafikeng, South Africa and Characterization Using Their Antibiotic Resistance Profiles. J. Pathog. 2014 ;371208.doi: 10.1155/2014/371208

38. Losch LS, Alonso JM, Merino LA. Occurrence of Antimicrobial Resistant Enetrobacteriacea in water from Different Sources in a Sub- Tropical Region of Argentina. Ambi Agua,Taubate, 2008;3:28-36. doi: 10.4136/AMBI-AGUA.50

39. Lynch JP, Clark NM, Zhanel GG. Evolution of antimicrobial resistance among Enterobacteriaceae (focus on extended spectrum b-lactamases and carbapenemases). Expert Opin. Pharmacother. 2013 ; 14: 199-210. doi: 10.1517/14656566.2013.763030

40. Atuanya El, Nwogu NA, Orah CU. Antibiotic resistance and plasmid profile of bacterial pathogens isolated from hair-dressing saloon effluents in Benin City, Nigeria. Nig. Jour. Life Sci. 2018;22(11):1749-1755. doi: $10.4314 /$ jasem.v22i11.7
41. Ash RJ, Mauk B, Morgan M. Antibiotics resistance of Gram negative bacteria in wells in United States. Emerg Infect Dis., 2002;8(7):713-716. doi: 10.3201/ eid0807.010264

42. Smith S, Aboaba OO, Odeigha P, Shodipo K, Adeyeye NN. Plasmid profile of Escherichia coli from water samples. African Journal of Biotechnology, 2003;2 (9): 322-324. Available online at http://www. academicjournals.org/AJB

43. Dale JW, Park S. Molecular genetics of bacteria $4^{\text {th }} \mathrm{Ed}$. John Wiley and sons Inc., Chichester, UK, 2004. https:// www.academia.edu/31746711/Dale_Molecular_ Genetics_of_Bacteria_4th_ed

44. Zhang $R$, Wang $Y, G u J D$. Identification of environmental plasmid-bearing Vibrio species isolated from polluted and pristine marine reserves of Hong Kong, and resistance to antibiotics and mercury, Antonie van Leeuwenhoek, 2006; 89(3-4):307-15 doi: 10.1007/ s10482-005-9032-z

45. Bennett PM. Plasmid encoded antibiotic resistance: acquisition and transfer of antibiotic resistance genes in bacteria, Br J Pharmacol, 2008; 153(Suppl. 1): S347-S357. doi: 10.1038/sj.bjp.0707607

46. Atuanya El, Nwogu NA, Orah CU. Antibiotic Resistance and Plasmid Profiles of Bacteria Isolated from Abattoir Effluents around Ikpoba River in Benin City, Nigeria J. Appl. Sci. Environ. Manage. 2018;22 (11) 1749-1755. doi: 10.4314/jasem.v22i11.7 